\title{
Do Corporate Social Responsibility Initiatives Favorable for Banks? Customer's Perceptions
}

\author{
Shahbaz Khan \\ Research Scholar, Shaheed Zulfikar Ali Bhutto \\ Institute of Science and Technology, Islamabad, Pakistan \\ Tel: 92-334-793-1215Ｅ-mail: shahbaz.khans2011@ gmail.com \\ shahbaz.khans@yahoo.com \\ Nida Baig \\ International Institute of Islamic Economics \\ International Islamic University, Islamabad, Pakistan \\ E-mail: nida_iiie@yahoo.com
}

Aon Waqas Awan

PhD Scholar, Environmental Economics \& Tourism

Universitat de les Illes Balears, Spain

Tel: 34-695-718-268Ｅ-mail: aon_waqas@yahoo.com

Muhammad Imdad Ullah

Research Scholar, Shaheed Zulfikar Ali Bhutto

Institute of Science and Technology, Islamabad, Pakistan

Tel: 92-300-635-0086_Email:imdadbzu@gmail.com

Received: March 12, 2014 Accepted: March 25, 2014

doi:10.5296/ber.v4i1.5266 URL: http://dx.doi.org/10.5296/ber.v4i1.5266 


\section{Abstract}

The main purpose of this research is to investigate the response of Pakistani banking customers towards corporate social responsibility initiatives. This study also seeks to investigate the importance level of each initiative as per the customers' perceptions.

The sample includes 300 banking customers of Rawalpindi and Islamabad in Pakistan. The data has been collected by survey methodology from banking customers of Habib Bank Limited and United Bank Limited through the use of a structured questionnaire. Regression and correlation have been employed as data analysis techniques. After the data analysis, it has been concluded that banking customers are entirely in the favor of taking CSR initiatives in the banking industry. The results also show that banking customers have given the highest priority to customer centric initiatives, with the philanthropic initiatives at the $2^{\text {nd }}$ and, environmental initiatives at the last.

Keywords: Corporate social responsibility, Customer-centric Initiative, Philanthropic Initiative, Environmental Initiative, Stakeholder Theory

\section{Introduction}

Banks operate as financial intermediaries in the economy. The banks supervise borrowers and handle the financial risks. Banks systemize the payment system in the society. As these functions have a huge impact on society; that's why banks have a massive impact on society (Scholtens, 2009). In the mid 1980's a new kind of bank comes out that has changed the market trend and has a strategy to quantify its profitability both financially as well as socially (Relano, 2011).

Internationally Banks are transferring millions of dollars into many different types of corporate social responsibility initiatives in order to fortify their reputation and get healthy associations with stakeholders (McDonald \& Rundle-Thiele, 2008). So, they are including social and environmental added value to their business operations and actions (Relano, 2011). Banks and financial organizations from every part of the world are directing their efforts to adopt corporate social responsibility practices and take on such policies which are not only beneficial for already established sections of society but also to upgrade economically marginalized classes.

Global overview of the banking industry reveals that their microfinance, microcredit schemes, ethical practices at workplaces, investment in the construction of social infrastructure are improving day by day. For instance, in India, the banking business gives attention to its corporate social responsibility actions, especially in the education sector, fair growth, physical health, and green marketing, and also takes into view the satisfaction of customers as a corporate social responsibility initiative (Narwal, 2007). Banking Industry of Taiwan has efficiently made use of CSR strategies for the improvement of the environment and to get the best customers outcome (McDonald \& Lai, 2011).

Word CSR firstly used by Bowen in 1953 in his book "Social Responsibility of the Businessman" Flack \&Heblich (2007). Flack \&Heblich (2007) argue that, within a decade, after the work of Bowen on CSR, many other researchers like Frederik (1960) and Davis (1960) 
broadly discussed the idea of CSR in their different debates. From that time, corporate social responsibility has taken an important place in debates of researchers and become the main subject for practitioners (Rahim et al., 2011). The key theme of corporate social responsibility is that, companies are restricted to do work for betterment of public (Safi, 2013).

The advantages of corporate social responsibility for banks are growing strongly and putting their positive impacts on earnings, faith, trust and customer retention (Brown \& Dacin, 1997; Sen \& Bhatachara, 2001). Due to these positive impacts, the banking sector has moved its attention towards adopting corporate social responsibility strategies.

For the last two decades, in Pakistan, the need of corporate social responsibility has been increased in the business community as well as for the satisfaction of their customers (Safi, 2013). Now the Pakistani banks too, are deeply involved in improving CSR activities by improving their workplaces, reducing the paperwork to avoid garbage by adopting the electronic banking techniques and investing in various social NGO's and institutions those are working for the betterment of human beings. In the recent disasters of flood and earthquake; banks play their prominent role in the reconstruction of infrastructure and giving social services to people in the form of food, money and other things fulfilling the basic needs of life.

\subsection{Contextual Analysis}

\subsubsection{Corporate Social Responsibility in Pakistan: General Idea}

In some parts of Asia, including Pakistan, corporate social responsibility is steadily creating its space in the multinational and private sectors (Khan \& Nomani, 2002). There is a huge importance and effect of CSR initiatives on the reputation of organizations, as well as it provides a constructive framework for using the stakeholders efficiently and effectively (Ahmad, 2006). In a research of 568 listed and unlisted companies regarding donation giving activities, published by Pakistan Centre for Philanthropy, the researcher uses annual reports and many arrangements of interviews to get the results which showed that $64 \%$ of the PLCs reports have several social development initiatives. Even though, companies give generally for reasons of trust and humanity, tax profit, make better public relations and marketing benefits are known as a cause to some degree (PCP 2005: v).

Many Pakistani firms connected with corporate social responsibility actions approaching to standards of developed countries in order to distribute information about their efforts, using different types of media such as literature in printed form (e.g., PSO), the commercial website e.g. (www.crescent.com.pk, Crescent Steel and Allied Products). Company profiles that are published in the Pakistan's Economic Review are as follows:

- Mark passing references to environmental policies, a national business publication (National Refinery Limited, Economic Review 2005a)

- Corporate citizenship (Pakistan Petroleum Limited, Economic Review 2005c; Askari Bank, Economic Review 2005b)

- Health, environment and safety (English Biscuit Manufacturers, Economic Review 2002). 
In Pakistan, CSR started when it made partnerships with international NGOs (Khan \& Nomani, 2002), and because of international organizations reacted to alarms increased in urban countries in relation to the issues such as working circumstances in supply chain partners and child labor. The affairs of child stitches and football industry have been known very well (Khaliq, 2004) along with its unintentional consequences and effects for the local employees (Huselbe 2000; Bendel, 2005). More business in Pakistan, for example the industry that makes surgical apparatus and leather tanneries, have been the important point of non government organization (NGO) academic studies and action (summarized in Lund Thomsen et al., 2006). In the majority of cases, force for exercising the Corporate Social Responsibility activities emerge from worldwide customers who are not willing to bear any more unethical practices of child labour (Safi, 2013).

The Pakistani managers while implementing various CSR initiatives in banks mix the interests of various stakeholder groups. This is a big hindrance for implementation of CSR initiatives in the better way which leads them to the loss of strategic focus. Among the various stakeholder groups; customers are the most important one and managers don't take into account the attitude and behaviour of customers while implementing CSR initiatives. Also, they ignore the important aspect, which CSR initiatives contain the highest importance in the mind of customers, which one holds the lesser and, which one is at the bottom level. Such real time problems need to readdress the following questions:

1. How banking customers respond to various CSR initiatives?

2. How banking customers perceive customer-centric initiatives?

3. How banking customers perceive environmental initiatives?

4. How banking customers perceive philanthropic initiatives?

This paper attempts to investigate the impact of various corporate socially responsible initiatives on Pakistani banking customers and answer these questions.

\section{Literature Review}

\subsection{Concepts and Definitions (Corporate Social Responsibility)}

Corporate social responsibility arises from societal responsibilities, no matter what is the nature of these responsibilities (Craig, 2003). A concept of corporate social responsibilities varies from author to author, e.g. according to Craig (2003), the CSR is only fulfilling the responsibilities of organization's stakeholders and, on the other hand Brown \& Dacin (1997) explained CSR as the responsibility of whole society. Corporate social responsibility indicates working a business in a socially responsible way whereby the business:

- Undertakes labor by improving workplaces and ethical practices in employment;

- Is concerned in building local communities and communicates with apprehensive communities regarding the effects of its products and policies;

- Spends on building social infrastructure; 
- Donates to a cleaner environment, its sustainability and protection; and

- Contributes by the manner of its corporate governance to economic progress at large.

Corporate social responsibility has been explained from different points of view. It has confined to a narrow financial thinking which define CSR as a source to make the most profits to shareholders (Zenisek, 1979). A complete societal view of CSR presented as "the company's position and actions with respect to its perceived societal or, at least, stakeholder obligations" (Brown \& Dacin, 1997). CSR is illustrated with the intention to level up the focus of the enterprise on the numerous benefits of those who, on one side are affected by the result of its activity and on the other hand can control the overall performance of the enterprise (Zappi, 2007). Achua (2008) defines CSR as the social responsibility of a business which it has to fulfil due to its numerous interactions with environment and society. And according to Stuebs \& Sun (2011), it is the corporate objective of an organization in which a business organization has to include the interests of the society as well in their routine operations.

According to Nwankwo (1991) a bank's CSR obligations comprises of a corporate social duty to several stakeholders: to meet the demand of depositors one must maintain best possible liquidity, satisfy the reasonable deficits area demand for credits, to maximize profit for shareholders, conform with s of regulators to go on in business, economy and also satisfy its area population.

A significant effort to identify the positive effects of corporate social responsibility initiative has been done by many researches.

\subsection{Various CSR Initiatives and Measures}

There are following three types of CSR initiatives (McDonald \& Lai, 2011).

\subsubsection{Environmental-Protection Initiatives}

These include following type of measures:

- Reduce electricity and power consumption

- Use of environmental pleasant products

- Use of eco-friendly materials

Pakistani banking customers is now aware of the fact that it is the core responsibility of the banks to include also environmental protection measures while achieving their organizational goals (Safi, 2013). Also the managers in all around the world are progressively hopeful to be focused on the performance of environmental and social responsible issues. In various countries corporate social responsibility initiatives are implying by the initiative authoritarians, and also growing up by IMF, World Bank and OECD (Jenkins, 2005; Hafsi \& Farashahi, 2005).

\subsubsection{Customer-Centric initiatives}

- The workforce is competent and trustworthy 
- Staff has ability to solve the complaints.

- Positive and quick response of employee towards customer's queries.

- Staff is proficient and elegant.

- Extending the branch network as well as new stuff.

- ATM connectivity

- Faster internal processing

- A higher return and lower fees

- Internet and mobile banking

- Convenient and better branch environment

Rashid (2010) stated that overall strategies of an organization are specifically related to customer's satisfaction, so investors try to invest in those companies where they can earn not only the profit but also concerned with the company's worth related to customer satisfaction. Carrol (1979) defined the core object of business operations that is economic stability, which can be also obtained by customer centric initiatives.

According to Rashid (2010) there are four aspects of the customer centric initiative involved in corporate social responsibility activities of banks. The focus of these corporate social responsibility initiatives is on the following main points:

1. Spending more and more for quality improvement and innovation.

2. Setting up ethics in daily operations.

3. Contribute for a fruitful social change.

4. Following up legal regulations.

It is clear from the above mentioned four points that, corporate social responsibility is much more than its traditional concept i.e. to perform only philanthropic activities.

\subsubsection{Philanthropic Initiatives}

- Granting shows and concerts

- Giving funds an art exhibition

- To give awareness about financial planning to the common man by organizing different free workshops.

- Charity to orphanages.

- Funding for the building of schools in order to provide free education to poor children in remote areas.

Caroll (1991) suggested that for employees and managers, it is imperative to donate in 
charitable actions at their national level, especially in activities which have done for increasing the standards of society's lifestyle. Philanthropic obligations are not as like ethical responsibilities as they are just an option, depends on the consent of managers of organizations, it does not relate to the organization's profit (Farell, 2004). In fact, the purpose of philanthropic responsibilities in an organization is to advertise the corporate social responsibility demonstration in developing parts of the world (Ahmed, 2006; Amaeshi et al., 2006; Arora \& Puranik, 2004). Organizations are not liable to fulfil their philanthropic aims, but it is best for their interest to accomplish their philanthropic responsibilities because of the pressure from society. Customers have a desire from organizations to donate their services, money and time in some volunteer activities (Caroll, 1991). Philanthropic responsibilities do not give any benefit in monetary terms for the short run, but it is very beneficial for a sustainable growth (Fombrun et al., 2000).

\subsection{Reaction of Banking Customers towards CSR Initiatives}

A lot of time and resources have been allocated by researchers and top executives to corporate social responsibility strategies in the recent decades (Cheng et al., 2014) but it is a viable methodology to keep out the financial companies from any type of comparative study and analysis due to different financial structure of these organizations and same practice of exclusion has been adopted by the researchers while applying corporate social responsibility initiatives to banking sector (Crowther \& Aras, 2010). No doubt, a lot of importance and stress is being given on CSR initiatives but still there is a gap lying for the studies based on customer's attitude and behaviour towards CSR initiatives (McDonald \& Rundle-Thiele, 2008). Not enough, researchers have thought about the reaction of banking customers towards the different CSR strategies (McDonald \& Lai, 2011).

\subsection{Stakeholder's Attitude towards CSR}

Theory of stakeholder supports strongly the companies to adopt a corporate social responsibility strategy (Safi, 2013). According to Reverte's (2009) “theory of stakeholder", every stakeholder group has its own point of view about the operations of an organization to be conducted; that's why organization should deal each group of stakeholder independently. Stakeholder perspective urges the managers and theorists to think about the new ways and policies which enable them to deal properly with stakeholders in such a balanced way that may benefit both the sides equally (Bhattacharya, 2009). So, Bhattacharya (2009) has a view that, if a company wants to get good returns through corporate social responsibility practices, it should have to provide a particular return to individual stakeholders. Turnover and policies of an organization are interdependent (Rashid, 2010). So, to earn better profits ethical, legal and social structure of the organization should be developed in accordance with the interests of the relevant stakeholders (Rashid, 2010).

According to Rashid (2010), there should be one central stakeholder in focus because targeting the satisfaction of multiple stakeholders will cause in loss of corporate strategic focus and will create dissatisfaction. Actually, it's rather critical to choose a central stakeholder in the sense that his satisfaction should also result in satisfaction of other stakeholders as well (Rashid, 2010). In the majority of cases customers are the central stakeholders and main point of focus 
due to their presence as major citizens of society (Rashid, 2010). Consequently, the strategy which is customer oriented will obviously satisfy the overall social demand of the stakeholders involved (Rashid, 2010).

\subsection{CSR Initiatives Impact Customer Approach and Attitude}

There are few studies available to investigate the relationship between the customer behaviour and corporate social responsibility; many research analysts suggested that organizations should properly advertise corporate social responsibility sequentially to get a positive effect on the customer's attitude (Maignan \& Ferrel, 2001). Opposing consequences were discovered about the effects of social corporate responsibility on the customer's attitude (Ali et al., 2010). It has been revealed by some researchers that corporate social responsibility initiatives are directly related to intentions of consumers to buy something (Ellen, Webb, 2000; Creyer \& Rose, 1997).

A little bit of literature found in the banking sector which shows the effect of corporate social responsibility initiatives on the customer's attitude and behaviour attentions. McDonald \& Lai (2011) have investigated that customer oriented initiatives have a stronger positive impact on the attitude of customers as compared to other CSR initiatives. Also in their findings, they concluded that customer oriented initiatives have a great positive impact on the customer's behaviour as compared to other initiatives. Some literature has defined the behaviour effectiveness in corporate social responsibility fields (Sen et al., 2006). Sen et al. (2006) discovered that, people who have a good awareness about a real business philanthropy initiative are more intent to invest and purchase. It is discovered that, "Massachusetts Bank" has been successful in getting new accounts, approximately 138 accounts having worth $\$ 11$ million, by helping out the animal class which are in danger of extinction with providing funds to World Wildlife Fund (Lamke, 1987).

Studies, which may have an impact on the attitudes and behaviours of customers, are very few; but a lot of studies have ranked the customer's preferences towards different corporate social responsibility initiatives (McDonald \& Lai, 2011). McDonald \& Lai (2011) studied the responses of customers of Taiwanese retail banking towards different CSR initiatives and concluded that, customers prefer customer oriented initiatives more as compared to environmental and community related initiatives. Customers have a point of view if they are satisfied; this should lead to the satisfaction of all the relevant stakeholders as well (Rashid, 2010). So, customers prefer the initiatives such as ATM connectivity, faster internal processing, higher return and lower fees, internet and mobile banking, excellent dealing with employees with them and of course the convenient and better branch environment (Rashid, 2010). McDonald \& Rundle-Thiele (2008) also concluded that customer centric initiatives provide more satisfaction to bank customers as compared to philanthropic and environmental protection initiatives.

Maginan \& Ferel (2004) identified many studies about the positive effects of corporate responsibility initiative on customers by reviewing the literature. It is noted by Handlman \& Arnold (1999), that the actions which are committed by customers, and related to institutional standards, have been taken by customers positively. Consumers prefer the companies who are 
related to commit actions of friendly environment ethics (Brone et al, 2000).

According to Murry \& Vogel (1997), various socially responsibility programs effects on customers like cause support (a latchkey program for children), friendly environment, customer centric initiative, and also includes customer security (a program of consumer board).

\subsection{CSR Initiatives in Banking}

Mcdonald \& Lai (2011) conducted a study on two forms of social marketing in banking sector in Taiwan and concluded that consumers encourage the concept of social marketing. A study conducted in the retail banking sector of Spain by taking a sample of 800 customers, De los Salmones et al., (2009) inspected that both ethical \& philanthropic initiatives have a positive impact on customer loyalty.

Previous literature and studies recommended that customer oriented initiatives can encourage the positive approach of the customers. So, the banks may get the competitive edge by giving more preference to customer oriented initiatives (McDonald \& Rundle-Thiele, 2008).

In the light of previous studies and the discussion about how customers rank various CSR initiatives, it may be suggested that customer centric initiatives contain higher importance for enhancing the attitudes and behaviour of customers as compared to philanthropic and environmental initiatives.

\section{Hypotheses and Theoretical Framework}

\subsection{Hypotheses}

$\mathrm{H}_{1}$ : CSR initiatives impact positively on the attitude and behaviour of customers

$\mathrm{H}_{2}$ : Banking customers give the highest priority to customer centric initiatives

$\mathrm{H}_{3}$ : Banking Customers give the lesser priority to philanthropic initiatives

$\mathrm{H}_{4}$ : Banking Customers give the least priority to environmental initiatives

\subsection{Theoretical Model}


Figure l. Theoretical Model

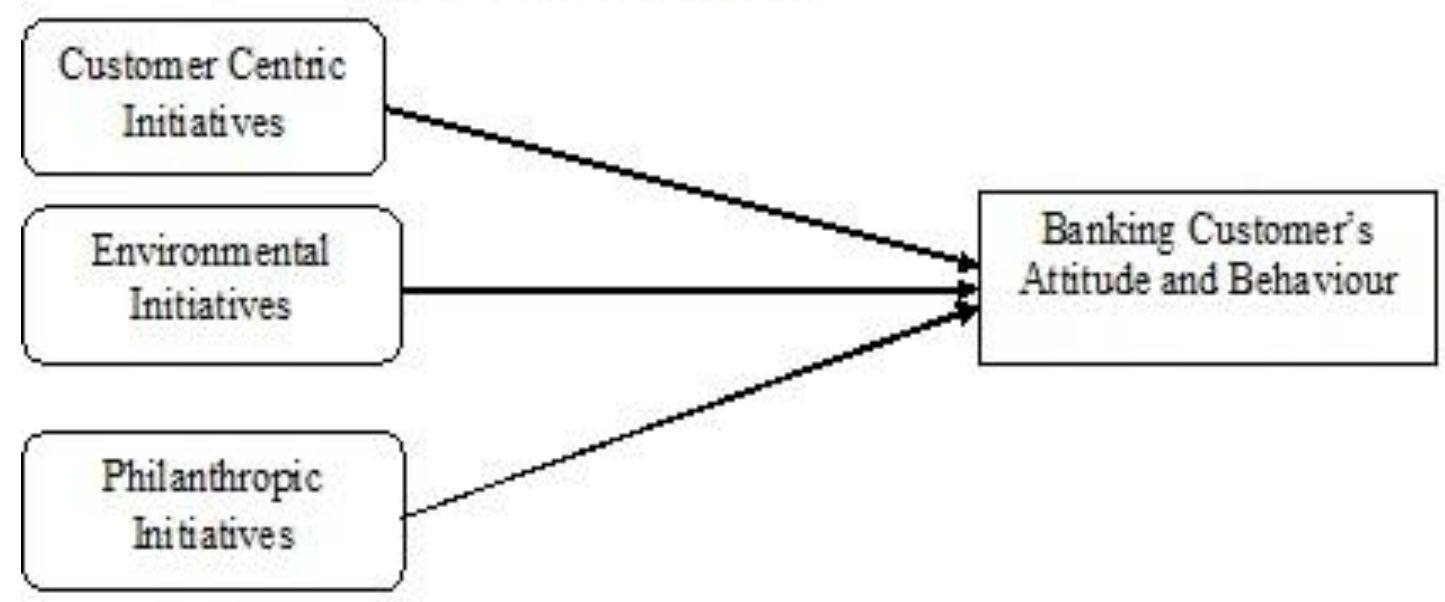

\section{Methodology}

\subsection{Sample Size}

The decision of the sample size is very necessary for getting best statistical analysis. So the sample size used consists of 300 questionnaire responses. However, it can vary between 100 to 300. The more the responses the more efficient statistical analysis will be. The data thus gathered should be examined without any delay in order to prove our hypotheses.

\subsection{Population Frame}

It is highly confidential to get the list of a bank's customers. My actual population frame was the bank statement which consists of the list of all customers; however, it was not possible to get that statement. So, I personally visit both the banks and filled my questionnaires on a random basis from the customers entering into the branches.

\subsection{Pilot Testing}

Collection of data is being done via an adapted questionnaire. So, it is mandatory to check its validity in the real banking environment of Pakistan. In order to have a glimpse, whether banking customers are aware of the corporate social responsibility's concept or not; I have visited personally to various banks of Rawalpindi \& Islamabad and routed a set of 50 questionnaires. I had asked each and every respondent whether he is able to under the questions or not. Are they satisfied with the language, wording and number of options in each question? The feedback from most of the respondents was positive. 48 out of 50 respondents were satisfied with the questionnaire which was enough for my questionnaire to be proved as valid.

\subsection{Survey Methodology}

Questionnaire surveys have been broadly recognized as competent tools for evaluating the perception of persons over and above of the company on an exacting subject. This does not denote, on the other hand, that the limitations of this tool are to be ignored. In societal research, one of the middle issues of the reviewers of the questionnaire is how it is able to be assured that the respondent interpret in such a way that the researcher needs. These problems can be 
overcome by a careful design, as most troubles stem from a misinterpretation of the sense of the concepts enclosed and tendency to pursue systematic response patterns.

\subsection{Measuring Instrument}

The questionnaire was used as an instrument for primary data collection. It contained 5 point lekert scale items. To measure customer's attitude and behaviour, the 6 items were adapted from Baumann et al. (2007) (I and satisfied with the services of the bank and I like it, I have a better feeling about my bank, my experience with the bank is good), including 3 other items to measure their behaviour (I shall always give a positive comment about my bank; if anyone else asked about it, if I have a choice to choose in some other geographical area; I would recommend to select it again, I enjoyed visiting bank).

The 6 items of customer centric initiatives were adapted from Rashid (2010). Philanthropic initiatives are measured by six items, adapted from McDonald \& Chia (2011) and, environmental initiatives are being measured by the components adapted from Jenkins (2005).

\section{Data Analysis}

To test the reliability, the reliability " $\alpha$ " scores for all the variables used is calculated first. T-test is applied to test acceptance or rejection of null hypotheses. F-test is applied to check the fitness of the model. Coefficient of variation $\left(\mathrm{R}^{2}\right)$ is calculated to explain how much change in our dependent variable is due to the independent variables. Then the simple regression model is applied to find out the relationship between the independent and dependent variables. To measure the degree of relationship of each explanatory variable on dependent variable, correlation analysis is performed.

\subsection{Data Analysis Techniques}

The SPSS 17 was used as an instrument for analysis to measure the responses or feedback from the banking customers.

\subsection{Data Analysis and Results}

Table 1. Descriptive Stat for Age

\begin{tabular}{|l|l|r|r|r|c|}
\hline & & Frequency & Percent & Valid Percent & Cumulative Percent \\
\hline Valid & $18-25$ & 52 & 17.3 & 17.3 & 17.3 \\
\cline { 2 - 6 } & $26-30$ & 114 & 38.0 & 38.0 & 55.3 \\
\cline { 2 - 6 } & 31 and above & 134 & 44.7 & 44.7 & 100.0 \\
\cline { 2 - 6 } & Total & 300 & 100.0 & 100.0 & \\
\hline
\end{tabular}

Table 2. Descriptive Stat for Gender

\begin{tabular}{|l|c|r|r|r|c|}
\hline & & Frequency & Percent & Valid Percent & Cumulative Percent \\
\hline Valid & Male & 207 & 69.0 & 69.0 & 69.0 \\
\hline
\end{tabular}




\begin{tabular}{|l|l|r|r|r|r|}
\hline & Female & 93 & 31.0 & 31.0 & 100.0 \\
\cline { 2 - 5 } & Total & 300 & 100.0 & 100.0 & \\
\hline
\end{tabular}

Table $1 \& 2$ shows the descriptive stat for the gender and age of the total respondents. Among the 300 respondents, $69 \%$ were males and remaining, $31 \%$ were females. And $45 \%$ of the respondents were of age 31 and above, $38 \%$ were aged between 26 and 30 while $17 \%$ were aged between 18 and 25 .

Table 3. Reliability of the Variables

\begin{tabular}{|l|c|c|}
\hline \multicolumn{1}{|c|}{ Construct } & Cronbach Alpha & No. of Items \\
\hline Customer's Attitude and Behavior & .74 & 6 \\
\hline Customer Centric Initiatives & .71 & 6 \\
\hline Philanthropic Initiatives & .78 & 6 \\
\hline Environmental Initiatives & .68 & 6 \\
\hline All Items(Questionnaire) & 0.77 & 4 \\
\hline
\end{tabular}

Table 3 shows the reliability of the generated scale. It is clear from the table that, the chronbach alpha values for all the variables are more than 0.7 except environmental initiatives which is slightly less. And according to Nunnally (1978), 0.7 is the acceptable reliability coefficient for a scale to be considered as reliable. Also, chronbach alpha value for whole questionnaire is 0.77 which is an evident that questionnaire is reliable and can be distributed for survey among banking customers.

Table 4. Coefficient of Determination

\begin{tabular}{|c|c|c|c|c|}
\hline Model & $\mathrm{R}$ & R Square & Adjusted R Square & Std. Error of the Estimate \\
\hline 1 & $.650^{\mathrm{a}}$ & .422 & .417 & .45558 \\
\hline
\end{tabular}

Table 4 shows the value of R-square (Coefficient of Determination). And the value of co-efficient of determination tells us that how much explanatory variables are explaining the dependent variable of the study. Here our R-square value is $42.2 \%$; it shows that $1 \%$ change in the independent variables (CCI, PI and EI) will cause a $42.2 \%$ change in the dependent variable $(\mathrm{CAB})$.

Table 5. ANOVA

\begin{tabular}{|c|c|c|c|c|c|c|}
\hline \multicolumn{2}{|c|}{ Model } & Sum of Squares & df & Mean Square & F & Sig. \\
\hline \multirow{2}{*}{1} & Regression & 44.932 & 3 & 14.977 & 72.162 & $.000^{\mathrm{a}}$ \\
\cline { 2 - 7 } & Residual & 61.435 & 296 & .208 & & \\
\cline { 2 - 7 } & Total & 106.367 & 299 & & & \\
\hline
\end{tabular}


a. Predictors: (Constant), EI, CCI, PI

b. Dependent Variable: CAB

Table 5 shows the fitness of model. If the calculated value of $\mathrm{F}$ is greater than the tabulated value at a significance level of 0.05 . Then we say that our model fits and the null hypothesis is rejected. The calculated value of $\mathrm{F}$ for this study is 72.16 and tabulated values for $\mathrm{F}$ at the above mentioned significance level are 8.55 with degree of freedom 3 . That's why model of this study is fit.

Table 6. Results of Regression

\begin{tabular}{|c|c|c|c|c|c|c|}
\hline \multirow{2}{*}{\multicolumn{2}{|c|}{ Model }} & \multicolumn{2}{|c|}{ Unstandardized Coefficients } & \multirow{2}{*}{$\begin{array}{c}\text { Standardized Coefficients } \\
\text { Beta }\end{array}$} & \multirow{2}{*}{$\mathrm{t}$} & \multirow{2}{*}{ Sig. } \\
\hline & & B & Std. Error & & & \\
\hline & (Constant) & .289 & .248 & & 1.165 & .245 \\
\hline \multirow{3}{*}{1} & $\mathrm{CCI}$ & .371 & .055 & .334 & 6.798 & .000 \\
\hline & PI & .276 & .049 & .291 & 5.622 & .000 \\
\hline & EI & .242 & .062 & .209 & 3.902 & .000 \\
\hline
\end{tabular}

a. Dependent Variable: $\mathrm{CAB}$

Table 6 shows the regression relationship between the variables. It is visible from the beta values that explanatory and dependant variables have a positive relationship. As per above mentioned values of betas, the regression equitation will be as follows:

$\mathrm{CAB}=.289+.371 \mathrm{CCI}+.276 \mathrm{PI}+.242 \mathrm{EI}$

Above equation shows that all the independent variables have put a positive impact on the customer's attitude and behaviour. Hence, $1^{\text {st }}$ Hypothesis is accepted.

Table 7. Results of Correlations

\begin{tabular}{|c|c|c|c|c|c|}
\hline & & CAB & CCI & PI & EI \\
\hline CAB & Pearson Correlation & 1 & & & \\
\hline CCI & Pearson Correlation & $.517^{* *}$ & 1 & & \\
\hline PI & Pearson Correlation & $.507^{* *}$ & $.335^{* *}$ & 1 & \\
\hline EI & Pearson Correlation & $.491^{* *}$ & $.410^{* *}$ & $.501^{* *}$ & 1 \\
\hline
\end{tabular}

**. Correlation is significant at the 0.01 level (2-tailed)

Table 7 shows that banking customers have given the highest priority to customer centric initiatives than other two initiatives as having the highest correlation coefficient of 0.517 . Customers have kept the philanthropic and environmental initiatives at the $2^{\text {nd }}$ and $3^{\text {rd }}$ priorities 
respectively. It is an evident that $2^{\text {nd }}, 3^{\text {rd }}$ and $4^{\text {th }}$ hypotheses for this study are also accepted.

\section{Results and Discussion}

The contribution of this research regarding the response of Pakistani banking customers towards the corporate social responsibility initiatives is as follows:

$\mathrm{H}_{1}$ predicted that, CSR initiatives will create a significant positive impact on the attitude and behaviour of banking customers. It is visible from the regression equation that, the independent variables, i.e. CCI, PI and EI are impacting positively on customer's attitude and behaviour. Also, the impact is significant at 0.01 level.

According to the prediction of $\mathrm{H}_{2}$, banking customers should give the highest priority to customer-centric initiatives as compared to other two. And the correlation table showed that customer centric initiatives have the highest correlation coefficient i.e. 0.517 as compared to the other two initiatives which is the evidence of banking customer's highest priority and interest towards customer-centric initiatives; proving our $2^{\text {nd }}$ hypothesis as well.

$\mathrm{H}_{3}$ and $\mathrm{H}_{4}$ suggested that, banking customers will give $2^{\text {nd }}$ and $3^{\text {rd }}$ priority to philanthropic and environmental initiatives respectively. The correlation coefficients for these initiatives (PI: $r=$ 0.507; EI: $r=0.491$ ) demonstrated that customers gave a 2nd ranking to philanthropic initiatives and $3^{\text {rd }}$ ranking to environmental initiatives. This verified our $3^{\text {rd }}$ and $4^{\text {th }}$ hypotheses as well.

The results of this study are similar to the study of McDonald \& Chia (2011) who have investigated the "impact of CSR initiatives on Taiwanese banking customers. So, the same results are applicable for Pakistani banking customers as well.

\section{Conclusion}

The foremost objective of this research was to investigate the impact of CSR initiatives on attitude and behaviour of banking customers. Therefore, the findings of this study are especially beneficial for the banking sector of Pakistan. It is apparent from the results that, all our Hypotheses are true which means that CSR initiatives have a positive and significant impact on the attitude and behaviour of Pakistani banking customers. The second objective of this study was to determine the priority of banking customers towards various CSR initiatives. For this, we have to check that up to what extent there is a change in dependent variable, i.e. in attitude and behaviour of banking customers due to each independent variable. As correlation is the way to determine the degree or extent of relationship between explanatory and dependent variables. The results of the correlation indicated that due to customer centric initiatives, there occurred a more significant change as compared to other two initiatives. Therefore, we can conclude that banking customers are very much interested in those initiatives which are in their own favor. Psyche of human beings always shows flexibility towards its own benefits. And the same type of attitude and psyche of customers can be observed in this study.

From results, it can also be inferred that customers are keeping philanthropic initiatives at the $2^{\text {nd }}$ priority and, environmental initiatives at the last. Although there is a difference between, the correlation coefficient of all the three initiatives, but the difference is slight. This slight 
difference is also indicating that, banking customers want an improvement in the customer service, but at the same time don't want to ignore the discretionary societal concerns i.e. philanthropy and environmental.

\section{Policy Implications for Banks}

Researchers and bankers can use this study to understand the mindset of banking customers at the time of taking CSR initiatives in banking sector of Pakistan. Pakistani banks should ensure of stake holder's CSR needs and preferences as there is a difference between stakeholder's view and needs of CSR. And, to fulfil this need of stakeholders; banks should commence a more holistic stakeholder approach towards the improvement of CSR strategies. An organization must pay attention towards stakeholder approach because history reveals that the companies who realize the priority concerns of stakeholders are performing better than the organizations that don't care of these interests. Also, the role of customers should outweigh other stakeholder groups. So, the banks should construct such policies for implementation of CSR strategies in which customer should be on the top of list as compared to other stakeholders. And when customers are happy, they will prioritize to use that banking products. As a result, this will help in improving both the financial and economic performance of banks.

\section{Limitations and Future Recommendations}

In both of the banks, i.e. UBL and HBL, more customers are males and above 26 years of age. So, young banking customer's (18-25) response is much less and consists of only $17 \%$ of the total respondents. Similarly, there are only $31 \%$ of female banking customers in the sample due to the less number of female account holders in both of the banks. These are the main limitations from both of the banks, which resist the finding to be applicable to a wider community.

I have delimited my research only to banking customers; however the research may be done by taking into consideration the other stakeholder groups. Moreover, I have taken only two banks in my sample size located in Islamabad and Rawalpindi and, collected my data at one point of time. So, a cross sectional study is recommended by including all of the Pakistani banks for a better understanding of customer's mind and behaviour.

\section{References}

Achua, J. K. (2008). Corporate social responsibility in Nigerian banking system. Society and Business Review. 3(1), 57-71.http://dx.doi.org/10.1108/17465680810852748

Ahmad, S. J. (2006). From Principles to Practice: Exploring Corporate Social Responsibility in Pakistan. Journal of Corporate Citizenship. 2006(24), 115-129. http://dx.doi.org/10.9774/GLEAF.4700.2006.wi.00011

Ali, I. et al. (2010). Effects of corporate social responsibility on consumer retention in cellular industry of Pakistan. African Journal of Business Management, 4(4), 475-485.

Arora, B., \& Puranik, R. (2004). A Review of Corporate Social Responsibility in India.Development. 47(3), 93-100. http://dx.doi.org/10.1057/palgrave.development.1100057 
Baumann, C. et al. (2007).Prediction of attitude and behaviourial intentions in retail banking. International Journal of Bank Marketing. 25(2), 102-116. http://dx.doi.org/10.1108/02652320710728438

Bhattacharya, C.B. et al. (2009). Strengthening stakeholder company relationships through mutually beneficial corporate social responsibility initiatives. Journal of Business Ethics. 85(2). 257-72. http://dx.doi.org/10.1007/s10551-008-9730-3

Brone, M. J. et al. (2000). The influence of cause related marketing on consumer choice: does one good turn deserve another? Journal of Academy of Marketing Science. 28(20), 248-62. http://dx.doi.org/10.1177/0092070300282006

Brown, T. J., \& Dacin, P. A. (1997), The Company and the product: corporate associations and consumer product responses. Journal of Marketing. 61(1), 68-84. http://dx.doi.org/10.2307/1252190

Carroll, A. B. (1991). The pyramid of corporate social responsibility: toward the moral management of organizational stakeholders. Business Horizons. 34(4), 39-48.

http://dx.doi.org/10.1016/0007-6813(91)90005-G

Chang, H-S.et al. (2009). How public-issue-promoted and revenue related types of social marketing influence customer perceived value in Taiwan's banking industry. Journal of International Consumer $\quad$ Marketing. $\quad 21(1), \quad 35-49$, http://dx.doi.org/10.1080/08961530802125308

Cheng, et al. (2014). Corporate social responsibility and access to finance. Strategic Management Journal. 35(1), 1-23. http://dx.doi.org/10.1002/smj.2131

Creyer, E. H., \& Ross, W. T. (1997). The influence of firm behavior on purchase intention: Do consumers really care about business ethics? Journal of Consumer Marketing.14(6), 421-432. http://dx.doi.org/10.1108/07363769710185999

De los Salmones, M. M. G. et al. The social role of Financial Companies as a Determinant of Consumer Behaviour. International Journal of Bank Marketing. 27(6), 467-85. http://dx.doi.org/10.1108/02652320910988339

Ellen, P. S. et al. (2000). Charitable programs and the retailer: Do they mix? Journal of Retailing. 76(3), 393-406. http://dx.doi.org/10.1016/S0022-4359(00)00032-4

Ferrell, O. C. (2004). Business ethics and customer stakeholders. The Academy of Management Executive. 18(2), 126-129. http://dx.doi.org/10.5465/AME.2004.13836176

Flack, O., \& Heblich, S. (2007).Corporate Social Responsibility: Doing Well by Doing Good. Business Horizons. 50(3), 247-254. http://dx.doi.org/10.1016/j.bushor.2006.12.002

Fombrun, C. J. et al. (2000). Opportunity Platforms and safety nets: Corporate citizenship and reputational risk. Business and Society Review, 105(1), 85-106. http://dx.doi.org/10.1111/0045-3609.00066

Francesc, R. (2011), Maximizing social return in the banking Sector. Corporate Governance. 
11(3), 274-284. http://dx.doi.org/10.1108/14720701111138698

Hafsi T., \& Farashahi, M. (2005). Applicability of management theories to developing countries: a synthesis. Management International Review. 45(4). 483-511.

Handelman, J. M., \& Arnold, S. J. (1999). The role of marketing actions with a social dimension: appeals to the institutional environment. Journal of Marketing. 63(3), 33-48. http://dx.doi.org/10.2307/1251774

Jenkins R. (2005). Globalization, corporate social responsibility and poverty. International Affairs. 81(3), 525-540. http://dx.doi.org/10.1111/j.1468-2346.2005.00467.

Khan, F. S., \& Nomani, U. (2006). Corporate social responsibility and natural disaster reduction in Pakistan. Sustainable Development Policy Institute, www. sdpi. org, accessed 23 March.

Lemke, L. (1987). Current financial advertising: mass. Bank's evolutionary account also assists vanishing species. Bank Marketing. 19(5), 41.

Maignan, I., \& Ferrell, O. C. (2004). Corporate social responsibility and marketing: an integrated framework, Journal of the Academy of Marketing Science. 32(1), 3-19.

http://dx.doi.org/10.1177/0092070303258971

McDonald, L. M., \& Rundle-Thiele, S. (2008). Corporate social responsibility and bank customer satisfaction: a research agenda. International Journal of Bank Marketing. 26(3), 170-182.

McDonald, L.M. \& Hung, C.H. (2011). Impact of corporate social responsibility initiatives on Taiwanese banking customers. International Journal of Bank Marketing. 29(1), 50-63.

Murray, K. B., \& Vogel, C. M. (1997). Using a hierarchy-of-effects approach to gauge the effectiveness of corporate social responsibility to generate goodwill toward the firm: Financial versus nonfinancial impacts. Journal of Business Research. 38(2), 141-159. http://dx.doi.org/10.1016/S0148-2963(96)00061-6

Narwal, M. (2007), CSR initiatives of Indian banking industry. Social Responsibility Journal. 3(4), 49 60. http://dx.doi.org/10.1108/17471110710840233

Nunnally, J. (1978). Psychometric methods. McGraw-Hill, New York, NY.

Rahim, R. A. et al. (2011). The importance of Corporate Social Responsibility on conusmer behavior in Malaysia. Asian Academy of Management Journal. 16(1), 119-139.

Rashid,M. (2010),Customer Centric Corporate Social Responsibility, Retrieved from http://ssrn.com/abstract=1691563.

Reverte, C. (2009), Determinants of corporate social responsibility disclosure ratings by Spanish listed firms. Journal of Business Ethics. 88(2). 351-366. http://dx.doi.org/10.1007/s10551-008-9968-9

Safi, A., \& Ramay, M. I. (2013). Corporate Social Responsibility and Consumer Behavior: A 
Study from Pakistan. Information Management and Business Review. 5(4), 194-202.

Scholtens, B. (2009). Corporate social responsibility in the international banking industry. Journal of Business Ethics. 86(2), 159-75. http://dx.doi.org/10.1007/s10551-008-9841-x

Sen, S., \& Bhattacharya, C. B. (2001). Does doing good always lead to doing better? Consumer reactions to corporate social responsibility. Journal of Marketing Research. 38(2), 225-44. http://dx.doi.org/10.1509/jmkr.38.2.225.18838

Stuebs, M., \& Li-Sun (2011). Corporate social responsibility and firm reputation, Journal of Accounting, Ethics \& Public Policy. 12(1), Retrieved from http://ssrn.com1863343.

Zappi, G. (2007). Corporate responsibility in the Italian banking industry: creating value through listening to stakeholders. Corporate Governance. 7(4), 471-475. http://dx.doi.org/10.1108/14720700710820542

Zenisek, T. J. (1979). Corporate social responsibility: a conceptualization based on organizational literature. Academy of Management Review. 4(3), 359-68.

\section{Copyright Disclaimer}

Copyright reserved by the author(s).

This article is an open-access article distributed under the terms and conditions of the Creative Commons Attribution license (http://creativecommons.org/licenses/by/3.0/). 